Meta

Journal des traducteurs

Translators' Journal

\title{
Consecutive Interpretation: A Discourse Approach. Towards a Revision of Gile's Effort Model
}

\section{Guangjun Wu et Kefei Wang}

Volume 54, numéro 3, septembre 2009

URI : https://id.erudit.org/iderudit/038305ar

DOI : https://doi.org/10.7202/038305ar

Aller au sommaire du numéro

Éditeur(s)

Les Presses de l'Université de Montréal

ISSN

0026-0452 (imprimé)

1492-1421 (numérique)

Découvrir la revue

Citer cet article

Wu, G. \& Wang, K. (2009). Consecutive Interpretation: A Discourse Approach. Towards a Revision of Gile's Effort Model. Meta, 54(3), 401-416. https://doi.org/10.7202/038305ar
Résumé de l'article

En situation réelle d'interprétation consécutive, les interprètes professionnels peuvent, à l'occasion, réussir à combler l'écart entre la capacité mémorielle nécessaire et la capacité disponible lorsqu'ils traitent des segments extrêmement longs. L'existence de ces cas exceptionnels implique que le modèle d'efforts de Gile ne peut toujours s'appliquer et qu'il faut le compléter. Le présent article a trois objectifs. Premièrement, il cherche à proposer une solution à ce problème. Deuxièmement, il vise à spécifier les règles de transformation discursive en contexte d'interprétation consécutive. Se fondant sur les propriétés de la mémoire et les caractéristiques de l'interprétation consécutive, nous considérons que chaque segment, qu'il soit court ou long, sera traité en tant que discours, pour laquelle on présume que la transformation résultante est la solution. Troisièmement, il vise à définir un modèle de transformation discursive optimal, qui puisse tout à la fois rendre au maximum le texte source et être réaliste en termes de charge mémorielle. Bien que l'auteur justifie son hypothèse en s'appuyant sur une étude observationnelle, d'autres données expérimentales sont nécessaires pour valider la théorie proposée.
Ce document est protégé par la loi sur le droit d'auteur. L'utilisation des services d’Érudit (y compris la reproduction) est assujettie à sa politique d'utilisation que vous pouvez consulter en ligne.

https://apropos.erudit.org/fr/usagers/politique-dutilisation/ 


\title{
Consecutive Interpretation: A Discourse Approach. Towards a Revision of Gile's Effort Model
}

\author{
GUANGJ U N W U \\ Beijing International Studies University, Beijing, China \\ ajun345@hotmail.com \\ KEFEI WA NG \\ Beijing Foreign Studies University, Beijing, China \\ kfwang@bfsu.edu.cn
}

\begin{abstract}
RÉSUMÉ
En situation réelle d'interprétation consécutive, les interprètes professionnels peuvent, à l'occasion, réussir à combler l'écart entre la capacité mémorielle nécessaire et la capacité disponible lorsqu'ils traitent des segments extrêmement longs. L'existence de ces cas exceptionnels implique que le modèle d'efforts de Gile ne peut toujours s'appliquer et qu'il faut le compléter. Le présent article a trois objectifs. Premièrement, il cherche à proposer une solution à ce problème. Deuxièmement, il vise à spécifier les règles de transformation discursive en contexte d'interprétation consécutive. Se fondant sur les propriétés de la mémoire et les caractéristiques de l'interprétation consécutive, nous considérons que chaque segment, qu'il soit court ou long, sera traité en tant que discours, pour laquelle on présume que la transformation résultante est la solution. Troisièmement, il vise à définir un modèle de transformation discursive optimal, qui puisse tout à la fois rendre au maximum le texte source et être réaliste en termes de charge mémorielle. Bien que l'auteur justifie son hypothèse en s'appuyant sur une étude observationnelle, d'autres données expérimentales sont nécessaires pour valider la théorie proposée.
\end{abstract}

\section{ABSTRACT}

In reality, expert interpreters from time to time do successfully tide over the gap between the capacity required and capacity available in dealing with extraordinarily large segments in consecutive interpretation. These exceptional cases imply that Gile's Effort Model does not always hold and requires to be supplemented. This paper attempts to: 1) advance a solution to the dilemma that, in processing large segments in consecutive interpreting, the working memory capacity available is more often than not smaller than the capacity required, hence supplementing Gile's Effort Model; 2) specify the rules of discourse transformation in consecutive interpretation; based upon the features of memory and consecutive interpretation, we deem that each segment, be it large or small, shall be processed as a discourse, the transformation of which is presumed to be the said solution; 3) and subsequently identify the optimal discourse transformation model, which is both capable of embodying the source text to the largest extent possible and achievable in terms of memory load. In addition, the author, through an observational study, justified the hypothesis. The validity of this theory, however, still requires further experimental evidence.

\section{MOTS-CLÉS/KEYWORDS}

modèle d'efforts, capacité exigée, capacité disponible, transformation du discours, interprétation consécutive

Effort Model, capacity required, capacity available, discourse transformation, consecutive interpretation 


\section{Introduction}

Gile (1995) outlined an Effort Model of consecutive interpretation, consisting of:

(1) Phase One: Interpretation $=\mathrm{L}+\mathrm{N}+\mathrm{M}+\mathrm{C}$;

(2) Phase Two: Interpretation $=\mathrm{Rem}+\mathrm{Read}+\mathrm{P}^{2}$

For consecutive interpretation to proceed smoothly, the following conditions must be met: ${ }^{3}$
(a) $\mathrm{LR}+\mathrm{NR}+\mathrm{MR}<\mathrm{TA}$
(b) $\mathrm{LR}<\mathrm{LA}$
(c) $\mathrm{NR}<\mathrm{NA}$
(d) $\mathrm{MR}<\mathrm{MA}$
(e) $\mathrm{CR}<\mathrm{CA}$

In simple terms, total processing requirements must not exceed the total available capacity. ${ }^{4}$

In accordance with Gile's Effort Model (Gile 1995), it seems that interpreters are only competent when the total available processing capacity is larger than the capacity requirements. Otherwise, errors will occur due to capacity deficit on the part of interpreters. According to Miller (1956), the number of units of capacity in the shortterm memory is fairly constant - seven plus or minus two items - regardless of the information each unit contains. For instance, the number of unconnected words that we can hold in immediate memory is about the same as the number of unrelated digits, even though a word contains much more information than a digit. We admit that there is a capacity constraint, and therefore Gile's model is powerful. The following is a segment of discourse together with its interpretation extracted from a joint press conference co-hosted by then U.S. President Bill Clinton and then Chinese Premier Zhu Rongji at the White House on April 8, 1999. The source discourse lasts 76 seconds, containing 193 English words. ${ }^{5}$

(1) Last point, we say what we get out of (2) he could have people ask him about that in China. (3) They could say (4) it is the United States, not the European Union that sponsors the human rights resolution. (5) The United States has stricter controls on technology transfer to China than in the other countries (6) which should be open. (7) Both of which are true. (8) But when we just give you one final example. (9) Take the WTO. (10) How could it possibly serve the America's interest not to open more Chinese market to America's workers, businesses and farmers? (11) We have much bigger share of our market in terms of export (12) than we have theirs. (13) How could it possibly be against our interests to bring more Chinese into contact with more Americans and (14) give more opportunities for Americans to honestly compete in the Chinese market? (15) I think (16) it is clear that the more we work together and talk together and more China is involved with the rest of the world, (17) more likely we are to reach positive outcomes. (18) That is the logic of the policy and (19) the logic of what we are doing in particular on WTO.

\section{Clinton}

最后,我想指出的是,中国同样那里的人可以提出和美国人接触可以得到什么好。那 么, 他可以说是美国而不是欧洲来提起这些关于人权的决议。他也可以说是美国而不 是欧洲有最严格的技术转让的控制。所以,这样说都是对。但是,我最后想提出的例子 是世界贸易组织的问题。谈到这个什么是符合美国利益的话呢。如果说更开放中国 市场,让美国的工人,美国的企业,美国的农民能够有更多机会。这怎么不符合美国的利 
益呢? 然后呢, 如果说能够让美国在中国的市场能够有更好的竞争机会和更好的市场 份额。这怎么不符合美国的利益呢? 我认为这样子做当然是符合我们的利益, 应该多进 行接触才是符合我们的利益。

Interpreter

A comparison between the source discourse and the interpretation will lead to the obvious conclusion that the underlined sentence in the original speech is not reformulated in the interpretation. Consequently, this omission constitutes a violation of the principle of fidelity, which poses a universal constraint for interpreters. What are the reasons for the mismatch between the source text and the target text? We assume that there are two possibilities: the interpreter's neglect of duty or the interpreter's incompetence. Apparently, the first possibility is to be discarded, for no interpreter wants to be accused of being unfaithful, especially on such a sublime occasion. Then it follows that the error may be due to the interpreter's inability to cope with such a long segment. Actually, the textual pattern analysis indicates that the interpreter's capacity is already almost exhausted near the end of the original speech. It is found that the second-to-last sentence "I think it is clear that the more we work together and talk together and more China is involved with the rest of the world, more likely we are to reach positive outcomes." in the original speech forms a threshold for the capacity available of this interpreter. The reasons are as follows. In the preceding sentences, we see a close correspondence between the source text and the target text. While dealing with the second-to-last sentence, the interpreter dropped the specific terms such as work together, talk together and positive outcomes, which carry the sentence's primary information, and resort to superordinate terms: 这样子做 (doing in this way), 利益 (interests). This overgeneralization indicates that the interpreter is already helplessly grappling with the gap between the capacity available and the capacity required on this occasion, for overgeneralization, in consecutive interpretation, is an expedient strategy only employed when you are short of resources. Therefore, on this occasion, it is perfectly reasonable to assume that the interpreter fails to capture what comes next owing to the exhaustion of the capacity available.

The due interpretation shall be as follows:

最后一点, 在你们说这些话的时候, 我们体会到什么呢? 在中国, 也会有中国人问他这 个问题。他们会说, 是美国而不是欧盟发起了人权提案。美国向中国转让技术实施的 管制, 要严于其他国家。这两点都说对了。

但是, 让我举个最后的例子, 就举世贸组织吧。不向美国的工人、商人和农民开放更多 的中国市场, 怎么可能服务于美国的利益呢? 他们在出口品方面在我国市场占有的份 额, 远大于我们在他们市场占有的份额。让更多的中国人与更多的美国人接触, 让美国 有更多的机会在中国市场公平竞争, 又怎么可能违背美国的利益呢?

我想, 有一点是清楚的: 我们在一起协作增多, 会谈增多, 而且中国与世界其他地方的 接触增多, 我们就更有可能取得积极的成果。这就是此项政策的逻辑, 特别是我们在 世贸组织所做的事情的逻辑。

Meanwhile, however, expert consecutive interpreters from time to time do succeed in translating segments that are a lot longer than the one above. Although the conditions laid down by Gile are not met, consecutive interpretation does "proceed smoothly." These exceptional cases imply that Gile's Effort Model does not always hold and needs to be supplemented. 
In addition, many studies compare the memory performance of novice and expert interpreters (Chincotta and Underwood 1998; Liu, Schallert et al. 2004; Nordet and Voegtlin 1998; Padilla Benítez 1995; Köpke and Nespoulous 2006). Köpke and Nespoulous (2006) conducted an in-depth investigation of working memory capacity among 21 professional interpreters (experts), 18 second-year interpreting students (novices) and two control groups (20 multilinguals and 20 students), involving three span task tests: reading or listening span; digit span and free immediate recall. It was found that there was no between-group differences in simple span tasks (involving short-term retention alone), but significant group effects were observed in higherorder cognition tasks (involving both short-term retention and processing), such as the listening span task, category probe task and free recall with articulatory suppression. This shows that interpreters stand out from others in terms of the Central Executive, namely the processing mechanisms, rather than short-term retention. What really counts for interpreters is the Central Executive component in working memory. Findings (Casado 1996; Moser-Mercer 2000; Köpke and Nespoulous 2006) show that expert interpreters are advantaged in such a task only if they can rely on semantic cues. Köpke and Nespoulous (2006: 17) claimed that this would mean that the semantic characteristic of the task is essential. So novice and expert processing are fundamentally different processes (Ivanova 1999; Moser-Mercer 2000; Köpke and Nespoulous 2006). As a result, we can conclude that research in consecutive interpretation should focus on processes, not capacity.

The purpose of this paper is, in terms of discourse, to map out a set of cognitive strategies to bridge the gap between limited capacity and actual demand for processing extraordinarily large segments in consecutive interpretation, and hopefully to supplement Gile's Effort Model. Our research questions are proposed as follows:

a) How to reconcile Gile's Effort Model with the reality that expert interpreters from time to time do successfully bridge the gap between the capacity required and capacity available in dealing with extraordinarily large segments in consecutive interpretation.

b) How a piece of discourse, especially an extraordinarily large piece of discourse, is processed in consecutive interpretation.

c) What the optimal discourse transformation model is in consecutive interpretation. As Van Dijk (1977: 146) claimed, a discourse has several levels of macro-structures. Therefore, it is of necessity to identify the most appropriate level of macro-structure that both embodies the source discourse and demands the minimal memory load possible.

\section{Discourse Transformation in Consecutive Interpretation}

Van Dijk (1977: 156) maintained that the major problem at issue for discourse is whether all propositions are stored in memory. This is clearly not the case when we look at free recalls of discourses of over 200 words. That is, beyond a certain threshold, a language user hearing or reading a discourse can no longer retrievably store all the semantic information of the discourse as a set or sequence of propositions. Herbert (1952: 67) stipulated that full consecutive interpretation should only take up $75 \%$ of the time taken by the speaker. Such a reduction was achieved by speaking at a faster pace and avoiding repetition, hesitation, and redundancy. As Pöchhacker (2004: 134) stated, the fact that compression (or abstracting) can be viewed not only 
as a "rescue technique" but also as a strategic orientation underlying the translational process is best illustrated with reference to consecutive interpretation. Dam (1993) concluded that "text condensing" was a necessary and usually good interpreting strategy. Sunnari (1995) and Pöchhacker (2004: 135) claimed that a "synthetic" rather than a "saying it all" approach rested on the basic strategy of "condensation." Mackintosh's experiment (1985) described the role of macro-structures in consecutive interpretation, but did not offer an explanatory account of their cognitive mechanism. So we will attempt to provide an explanatory account of the "condensation" in consecutive interpreting in terms of macro-structures.

The theory of macro-structures has been explored extensively (Bierwisch 1965; Van Dijk 1972, 1977, 1980; Van Dijk and Kintsch 1983; Kintsch and Van Dijk 1978). In addition, Van Dijk (1977) proved the existence of macro-structures in descriptive, narrative texts and conversations. A macro-structure of a sequence of sentences is a semantic representation of some kind, viz. a proposition entailed by the sequence of propositions underlying the discourse (or part of it) (Van Dijk 1977: 137). For example, topic is the highest level of macro-structure for a discourse. That is, macrostructures are not specific units. They are normal semantic structures of the usual propositional form, but are not expressed by a sequence of sentences rather than one clause or sentence. In other words, macrostructures are a more global level of semantic description; they define meaning of parts of a discourse and the whole of discourse on the basis of the meanings of the individual sentences. The basic hypothesis is that the amount of information presented must somehow be reduced and organized so as to remain available for retrieval in recall, in integration of incoming information, and in problem solving; and the operations would maintain the semantic "core" of a certain passage by constructing, during input, a macro-proposition representing the most "important" information of that passage. The theoretical stances are: 1) macro-structures are a necessary property of cognitive information processing and can account for cognitive information processing; 2) macro-structures constitute an integral part of the meaning of a discourse. The function of macro-structures is the organization in processing and memory of complex semantic information. Macrostructures are related to micro-structures by sets of semantic mappings. In other words, in order to obtain macro-structures of any sequence we must apply a number of operations. Since a certain amount of more detailed information becomes "lost" during these operations, we may speak of operations of semantic information reduction (Van Dijk 1977:143).

The rules for operations of macrostructures should be such that they operate on a sequence of macrostructures to yield still more global macrostructures, until the most general macrostructures of a discourse are generated. Van Dijk (1977), in this orientation, formulated four rules for macrostructure operations. ${ }^{6}$ A general constraint, holding for all rules, is:

For sequence $\Sigma=<\mathrm{P}_{1}, \mathrm{P}_{2},------, \mathrm{P}_{\mathrm{n}}>$ of propositions of a discourse and for any $\mathrm{P}_{\mathrm{i}} \in \Sigma$ : if there is a proposition $\mathrm{P}_{\mathrm{j}} \in \Sigma$, such that $\mathrm{P}_{\mathrm{i}}$ is a presupposition of $\mathrm{P}_{\mathrm{j}}$, then $\mathrm{P}_{\mathrm{i}}$ may not be deleted by macro-operations.

a) Rule One: DELETION.

Information is simply left out, along the following schema (where $\rightarrow$ denotes the semantic mapping [Van Dijk 1977: 144-146]):

fx \& gx $\rightarrow$ fx 
For example: town (a) \& little (a) $\rightarrow$ town (a)

The information deleted by this rule is accidental, or can be left out without changing the meaning or influencing the interpretation of the subsequent sentences of the discourse. Therefore, only those propositions that have an attributive predicate, not those that have an identifying or conceptual predicate, can be deleted with this rule. In the above example, "little (a)" is not a presupposition of any other proposition in the sequence, as is specified in the general constraint.

b) Rule Two: CONSTITUTION.

In fact, this is another deletion rule. The information deleted by this rule, however, is not accidental, but is constitutional of a certain concept or frame. It specifies normal causes and consequences of events, reasons and consequences of actions, normal components and the setting (time, place, world) of the object, event or action.

The schema for this rule is:

$<\mathrm{fx} \& \mathrm{gx} \& \mathrm{hx}>\rightarrow \mathrm{gx}$

Condition: gx $\square \rightarrow<$ fx \& gx \& hx $>$ (where $\square \rightarrow$ symbolizes a causal relation of necessitation and conditioning [Van Dijk 1977: 144-146])

The information deleted with this rule is inductively recoverable, which will have its consequences in cognitive processing.

c) Rule Three: SIMPLE GENERALIZATION.

With this rule, several objects or properties of the same superordinate class may be referred to, globally, with the name of the superordinate class. For example: "There were toys lying around." would express a macro-proposition for a sequence like: "There was a ball, a doll, a toy-car---, lying around." The information deleted in line with this rule is essential. As a result, the information in this case is irrevocable.

The schema for this rule is:

$<\mathrm{fx} \& \mathrm{gx}>\rightarrow \mathrm{hx}$

condition: (fx $\square \rightarrow \mathrm{hx}$ ) \& (gx $\square \rightarrow \mathrm{hx}$ )

d) COMBINED/INTEGRATED GENERALIZATION.

The information deleted with this rule is also of essential properties, components, causes, consequences, etc., of a higher-level fact, but is recoverable. For example: "I bought wood, stones and concrete; I laid foundations; I erected walls, I made a roof." may be subsumed under a proposition like "I built (a house)." because it is part of the more general concept or frame, although "house" and "built" are not mentioned.

The schema for this operation of integration is:

$<\mathrm{fx} \& \mathrm{gx}>\rightarrow \mathrm{hx}$

Condition: $\mathrm{hx} \square \rightarrow\langle\mathrm{fx} \& \mathrm{gx}>$

We deem that the first and the second rules are part of the same property and thus can be covered under one single heading, whereas the third and the fourth rules belong to different property and thus need to be arranged under two separate headings. Along this road, Van Dijk (1980; Van Dijk and Kintsch 1983) and Renkema (2004) came up with a three-component version:

a) DELETION: Given a sequence of propositions, delete each proposition that is not an interpretation condition (e.g., a proposition) for another proposition in the sequence. This rule subsumes rule one and rule two in the previous model.

b) GENERALIZATION: Given a sequence of propositions, substitute the sequence by a proposition that is entailed by each of the propositions of the sequence. That is, this rule converts a series of specific propositions into a more general proposition. This rule corresponds to rule three, namely simple generalization in the previous model.

c) CONSTRUCTION: Given a sequence of propositions, replace it by a proposition that is entailed by the joint set of propositions of the sequence. This rule corresponds to rule four, namely combined/integrated generalization in the previous model. 
The difference between the construction rule and the generalization rule is that the propositions on the basis of which a general proposition can be constructed do not have to be contained in the discourse. And in production, macro-rules operate in an inverse process, whereby the deletion is replaced by an addition rule; generalization by particularization; construction by specification. In comparison, we take this version as more concise and thus more operational.

The above model depicts the semantic mappings for discourse transformation. However, up to now, we are still confronted with two pending issues. First, no textual equivalents for propositions are proposed; hence the basic operational unit is absent. Second, no formal criteria are suggested as to whether one proposition is irrelevant for the interpretation of other propositions, whether several objects or properties of the same superordinate class can be globally subsumed under the name of the superordinate class, and whether several propositions can be constructed into one; hence the operational procedures are missing. In this regard, we deem that Halliday's Functional Grammar (1973; 1994) provides a handy option and we accordingly identify clause as the basic unit or the minimal semantic unit, namely the micro-structure. The reasons are as follows. First, in Halliday's theory, clause acts as the basic unit of the information structure of the discourse and possesses a lucid structural configuration: theme + rheme. The theme is the first element which serves as the point of departure of the message; it is that with which the clause is concerned. The remainder of the message, the part in which the theme is developed, is called the rheme. This coincides with our view of discourse comprehension as semantic information processing. On the other hand, the lucid and simple internal structure will pave the way for the deletion, generalization and construction among micro-structures. Secondly, the theme-rheme distinction is text-based. Its real value does not lie in explaining the structure of individual sentences but rather in shedding light on a number of important areas which control information flow (Baker 1992: 124). Halliday (1994: 61) also pointed out the choice of clause themes plays a fundamental part in the way discourse is organized; it is this, in fact, which comprises what has been called the "method of development" of the text. In this process, the main contribution stems from the thematic structure of independent clauses. But other clauses also come into the picture and need to be taken account of in theme-rheme analysis. This viewpoint fits squarely into our hypothesis of discourse transformation with the focus on the whole text. Hatim and Mason (2002) stressed the prominence of structure in consecutive interpretation.

That is, input for consecutive interpretation is characterized by texture being less readily usable than structure. In consecutive interpreting, effective reception and storage of information will involve focusing on the way a text is put together in response to context, and to the way texture is utilized to implement this. And effective consecutive output thus exhibits a clear outline of the way a text is structured. This compositional plan of the text will be the overall arrangement within which only relevant details of the textures and context are to be found. Certain kinds of contextual and textual information are liable to be jettisoned if they do not fit within the compositional plan in a way which contributes to making a sequence of sentences operational (Hatim and Mason 2002: 26).

The next problem then shall be how to delimit theme and rheme within a clause. To decide where the theme ends, Halliday (1994) suggests we refer to transitivity, 
which activates the clause as a representation. In its role as a representation, the clause sets up a model of human experience in terms of processes, which consists of three components: the process itself; the participants in that process; and any circumstantial factors such as time and place. The principle relevant to the thematic structure is this: the theme always contains one, and only one, of these experiential elements. this means that the theme of a clause ends with the first constituent that is participant, circumstance, or process. And the rest of the clause constitutes as the rheme. As our analysis of discourse in consecutive interpretation is mainly concerned with semantic information processing, in multiple themes, we only take the ideational component as the semantic core. In the following example, we take "on a week day" as the theme of the clause and "it would be less crowded" as the rheme.

TABLE 1

\section{Theme-Rheme pattern}

\begin{tabular}{|l|c|c|c|}
\hline On the other hand & maybe & on a weekday & it would be less crowded. \\
\hline Textual & Interpersonal & Ideational & \\
\hline \multicolumn{3}{|c|}{ Theme } & Rheme \\
\hline
\end{tabular}

In consecutive interpretation, we postulate three scenarios. First, when both the themes and the rhemes overlap in two or more clauses, only one clause is left and the rest is to be deleted according to the Deletion Rule. The schema for this operation is ${ }^{7}$ :

$$
\begin{aligned}
& <\mathrm{t}_{1}+\mathrm{r}_{1} \& \mathrm{t}_{2}+\mathrm{r}_{2}>\rightarrow \mathrm{t}_{1}+\mathrm{r}_{1} . \\
& \text { Condition: }<\mathrm{t}_{1}=\mathrm{t}_{2} \& \mathrm{r}_{1}=\mathrm{r}_{2}> \\
& \text { For example: } \\
& \text { "I do not believe this problem in this province is more serious than other parts of China } \\
& \text { although we are the gateway of China. I do not believe so." can be deleted as "I do not } \\
& \text { believe this problem in this province is more serious than other parts of China although } \\
& \text { we are the gateway of China." }
\end{aligned}
$$

Unlike in written discourses, in consecutive interpretation, this rule also deletes the redundancy, repetition, hesitation, corrections, etc, which characterize spontaneous talk.

Secondly, when themes and/or rhemes in two or more clauses can be subsumed under one superordinate class, the clauses can be generalized according to the Generalization Rule. The schema for this operation is:

$$
\begin{aligned}
& <\mathrm{t}_{1}+\mathrm{r}_{1} \& \mathrm{t}_{2}+\mathrm{r}_{2}>\rightarrow \mathrm{t}_{3}+\mathrm{r}_{3} \\
& \text { Condition: }<\mathrm{t}_{1} \square \rightarrow \mathrm{t}_{3}, \mathrm{t}_{2} \square \rightarrow \mathrm{t}_{3}>\&<\mathrm{r}_{1} \square \rightarrow \mathrm{r}_{3}, \mathrm{r}_{2} \square \rightarrow \mathrm{r}_{3}> \\
& \text { For example: } \\
& \text { "All present is requested to be seated. All the address } \\
& \text { into English, French, Chinese, Russian, German, } \\
& \text { eralized into" All present is requested to be seated. } \\
& \text { be interpreted into all of the major languages." } \\
& \text { Thirdly, when themes and rhemes in two or } \\
& \text { schema, the clauses can be constructed according } \\
& \text { schema for this operation is: } \\
& <\mathrm{t}_{1}+\mathrm{r}_{1} \& \mathrm{t}_{2}+\mathrm{r}_{2}>\rightarrow \mathrm{t}_{3}+\mathrm{r}_{3} \\
& \text { Condition: }<\mathrm{t}_{3} \square \rightarrow \mathrm{t}_{1} \& \mathrm{t}_{2}>\&<\mathrm{r}_{3} \square \rightarrow \mathrm{r}_{1} \& \mathrm{r}_{2}>
\end{aligned}
$$

"All present is requested to be seated. All the addresses and messages will be interpreted into English, French, Chinese, Russian, German, Spanish and Japanese." can be generalized into" All present is requested to be seated. All the addresses and messages will

Thirdly, when themes and rhemes in two or more clauses belong to a common schema, the clauses can be constructed according to the Construction Rule. The 
For example:

"Their labor cost is lower. Their investment return is higher." can be constructed into

"Their competitiveness is increasing."

In addition, we postulate that a discourse in consecutive interpretation undergoes rounds of discourse transformation. As the input is coming, each clause is perceived and integrated in line with the Deletion Rule, the Construction Rule and the Generalization Rule in sequence. In the first round, the Deletion Rule applies. In the second round, the Construction Rule comes into play prior to the Generalization Rule, for the information constructed is recoverable. In the third round, the Generalization Rule intervenes, for the information generalized is irrecoverable. Of course, in reality, the borders among the three rules are not that clear-cut and it is likely that they will mingle together to dictate the discourse transformation process. But we will adopt Beaugrande and Dressler's (1981: 42) notion of "Phases of processing dominance." That is, during one phase, one macro-rule dominates the process. And these rounds of operations are recursive. The macro-structure $\left(\mathrm{SM}_{2}\right)$ derived from the second round of transformation constitutes as the optimal discourse transformation model, providing that the capacity available is larger than capacity required. The general features of an optimal model are: it is fully capable of imitating the original system rationally, effectively and abstractedly; it is composed of the least number of essential constituents of the original system possible; it explicitly demonstrates the organic interrelationships between the constituents; it stands as close to the standard form as possible. Accordingly, $\mathrm{SM}_{2}$ is characterized by the following features at once: no redundant or incomplete theme-rheme pattern; be as close as possible to the speaker's thematic progression; propositions with the same theme or rheme are effectively combined; memory load is as small as possible. On condition that the capacity available is still not adequate, the discourse proceeds to the third round of transformation. And the operations persist until the capacity available and capacity required strike a balance. But the discourses derived from the third round and thereafter may suffer from overgeneralization, inaccuracy or loss of core semantic information; hence their validity degrades round after round in the context of consecutive interpretation. The above is our hypothesis of the process of discourse comprehension in consecutive interpretation.

\section{An observational study}

The following discourse is recorded from the consecutive interpretation performed by Zhang Jianmin (a senior interpreter with the Ministry of Foreign Affairs, People's Republic of China) at the press conference ${ }^{8}$ hosted by Premier Wen Jiabao for the third session of the Tenth People's Congress, PRC. (March 14, 2006). The source discourse runs 110 seconds and contains 439 words. ${ }^{9}$

(1)总理 $(t)$, 你好 $(r)$ ! (2)谢谢 $(t)$ 你给我机会提问 $(r) 。(3)$ 我 $(t)$ 有两个问题想问您 $(r)$ 。(4)首 先, 想问 $(\mathrm{t})$ 一下 $(\mathrm{r}),(5)$ 在过去的三年来 $(\mathrm{t})$, 我们发现言论自由受到更多的限制 $(\mathrm{r}),(6)$ 特 别 $(\mathrm{t})$ 是在互联网还有媒体上面 $(r),(7)$ 包括 $(\mathrm{t})$ 政府逮捕了一些在互联网上表达意见的 人士 $(\mathrm{r}),(8)$ 还有 $(\mathrm{t})$ 关闭了一些报刊 $(\mathrm{r})$ 。(9)我们 $(\mathrm{t})$ 也留意到 $(\mathrm{r}),(10)$ 在那个公安处理失 去土地的村民的那些活动, 那些抗议活动的时候 $(\mathrm{t})$, 越来越多那个用暴力 $(\mathrm{r})$ 。(11) 我 $(\mathrm{t})$ 想请问一下 $(r),(12)$ 你 $(\mathrm{t})$ 觉得用这些办法处理这些问题是适合的吗 $(\mathrm{r})$ ? (13) 是 $(\mathrm{t})$ 合适 的吗 $(\mathrm{r})$ ? (14)那你 $(\mathrm{t})$ 刚才提到要尊重农民的权利 $(\mathrm{r})$, (15)那为什么你 $(\mathrm{t})$ 会允许这些事情 
发生呢 $(r)$ ? (16)我 $(\mathrm{t})$ 还有第二个问题 $(r)$ 。(17)不 $(\mathrm{t})$ 好意思 $(\mathrm{r})$ 。(18)因为不是 $(\mathrm{t})$ 经常有机 会问您问题 $(r),(19)$ 还想 $(\mathrm{t})$ 多问一个 $(r)$ 。(20)我们 $(\mathrm{t})$ 也留意到, (21)在这几年来 $(\mathrm{t})$, 中国 有很多大的事故发生 $(\mathrm{r}),(22)$ 特别 $(\mathrm{t})$ 是在煤矿领域 $(\mathrm{r})$ 。(23)那我们 $(\mathrm{t})$ 也注意到政府也 采取了很多措施 $(r),(24)$ 包括 $(\mathrm{t})$ 惩罚一些不负责任的官员 $(\mathrm{r}),(25)$ 还有 $(\mathrm{t})$ 关闭很多煤矿 $(\mathrm{r})$ 。(26)可是, 我们 $(\mathrm{t})$ 也看到 $(\mathrm{r}),(27)$ 中国的煤矿工人 $(\mathrm{t})$ 还继续着大量的死亡, 受伤, 还 有中毒 $(r) 。(28)$ 那很多人 $(t)$ 觉得 $(r)$, (29) 唯一的这个解决这个问题的办法 $(\mathrm{t})$ 就是允许工 人有权利自由组织 $(r),(30)$ 不只是 $(t)$ 参加公司组织的那个工会 $(r) 。(31)$ 那能不能告诉

$(\mathrm{t})$ 我们 $(\mathrm{r})$, (32)中国政府 $(\mathrm{t})$ 会什么时候允许工人建立独立的工会呢 $(\mathrm{r})$ ?

AFP correspondent

According to Miller (1956) and Baddeley (1986), this discourse far exceeds the normal working memory capacity, whether in term of words, chunks, or duration. We posit that this discourse is transformed in the following manner.

\subsection{First Round of discourse transformation: Deletion}

The following underlined information is to be jettisoned without hurting the semantic core.

(4) 首先, 想问 $(t)$ 一下 $(r)$,

(10)在那个公安处理失去土地的村民的那些活动, 那些抗议活动的时候 $(\mathrm{t})$, 越来越多 那个用暴力 $(r)$ 。

(11)我(t)想请问一下 $(\mathrm{r})$

(12) 你 $(\mathrm{t})$ 觉得用这些办法处理这些问题是适合的吗 $(r)$ ? (13) 是 $(\mathrm{t})$ 合适的吗 $(\mathrm{r})$ ?

(27)中国的煤矿工人 $(\mathrm{t})$ 还继续着大量的死亡, 受伤, 还有中毒 $(r)$

Clauses (4) and (11) can be deleted, for their functions are merely interpersonal, not ideational. In clause (10), the underlined redundant information is to be deleted. In clause (12) and (13), the themes and rhemes are the same. Therefore, one of the clauses is to be deleted. In clause (27), the underlined serves as the modifier, so it can be deleted without impacting the interpretation of other clauses.

\subsection{Second Round of discourse transformation: Construction}

(3) 我 $(t)$ 有两个问题想问您 $(r)$ 。(4) 首先, 想问 $(t)$ 一下 $(r),(16)$ 我 $(t)$ 还有第二个问题 $(r)$ 。(17)不 $(t)$ 好意思 $(r)$ 。(18)因为不是 $(t)$ 经常有机会问您问题 $(r),(19)$ 还想 $(t)$ 多问 一个 $(r)$ 。

This round of transformation is not only significant but also necessary in consecutive interpretation, in particular in processing extraordinarily large segments. The construction operation, on the one hand, reduces the information load, but more importantly, integrates the discourse into an organized whole and thus sets up a common schema for information retrieval, for the information constructed is recoverable. As a result, clauses (3), (4), (16), (17), (18), and (19) can be subsumed under a single clause (3), which hierarchically controls the whole discourse. If the information is organized in a more meaningful and orderly way, the number of units can be reduced and accordingly more information will be sustained in the short-term memory. For example, it is incredibly difficult to remember the following 21-digit number: 00101011011110000101011 . However, we, after some observation and analysis, detect that the number is represented in a binary system. The rules within the system in 
question are: $000=0,001=1,010=2,011=3,100=4,101=5,110=6,111=7$. Up to now, we can reformulate the aforementioned 21-digit number in the following manner: 1267053 . It is a lot easier to memorize the seven-digit chunk than the 21-digit one.

\subsection{Third Round of discourse transformation: Generalization}

(5)在过去的三年来 $(\mathrm{t})$, 我们发现言论自由受到更多的限制 $(r),(6)$ 特别 $(\mathrm{t})$ 是在互联网 还有媒体上面 $(r),(7)$ 包括 $(t)$ 政府逮捕了一些在互联网上表达意见的人士 $(r),(8)$ 还有 (t)关闭了一些报刊 $(r)$ 。

The rheme in clause (5) is a superordinate class of the rhemes of clauses (6), (7) and (8), so the rhemes of this clause cluster can be subsumed under one common rheme, namely the rheme in clause (5). And this is also true of the following two clause clusters.

(23)那我们 ( $t$ )也注意到政府也采取了很多措施 $(r),(24)$ 包括 $(t)$ 惩罚一些不负责任的 官员 $(r),(25)$ 还有 $(\mathrm{t})$ 关闭很多煤矿 $(r)$ 。

(26)可是, 我们 $(\mathrm{t}$ )也看到 $(r)$, (27) 中国的煤矿工人(t)还继续着大量的死亡, 受伤, 还 有中毒 $(r)$ 。

The problem with this operation is that the information generalized is not recoverable. As a result, it only occurs as a rescue strategy on occasions when the capacity is spilled.

In addition, experiments (Li and Peng 1999) showed that Chinese-English bilinguals share a common semantic representation. So we assume that SM and TM also manifest a single semantic representation, viz., the same macro-structure. The transformation of $\mathrm{TM} \rightarrow \mathrm{T}_{\text {text }}$ is based on the rules governing the difference between the semantic representation and the surface structure of the target discourse. Now, let's come to the interpretation to verify our hypothesis.

I am with AFP. And I have a few questions to ask the Premier. As we have very limited opportunities to ask you questions, my questions are quite many here. In the past three years, we have found that more and more restrictive measures have been taken against the freedom of speech, particularly the speech on the internet. In this country, some people have been arrested for the expression of their opinions on the internet. Some newspapers or agencies have been closed due to the same reason. We have also noted that more violence has been used by the public security organs in dealing with the protesting farmers who have lost land due to the land seizures. We'd like to know do you think such kind of approach or practices appropriate? You just now in answering the questions mentioned that we need to respect the rights of the farmers of the countryside. This said, why do you allow such practice to take place? I would also like to know that in the past few years, there are quite a number of major accidents taking place in the coalmines in this country. The Chinese government has taken a host of measures to tackle this problem, including meting out harsh punishment against those irresponsible officials, closing down the coalmines. Despite all these measures, the Chinese workers continue to be killed, maimed or poisoned in those accidents. Many people believe that the only way out in this context is to allow the workers in this country to organize their own trade unions, instead of joining the trade unions set up by the companies that they work for. I would like to know, from you, Mr Premier, and when will Chinese government allow the workers to establish independent trade unions? Interpreter 
It is apparent that the aforementioned redundancy, repletion, hesitation, etc., was deleted from the interpretation due to the application of the Deletion Rule. The Construction Rule is successfully implemented to construct clauses (3), (4), (16), (17), (18), and (19) in the source discourse into two in the interpretation (the underlined). Unfortunately, the interpreter did not offer the discourse markers for the initiation of the two questions, which establish the frame of the discourse. No generalization is observed in the interpretation. To conclude, this interpretation constitutes a close correspondence to our hypothesis. And this interpreter showed marvelous aptitude in the area of discourse transformation.

Even small discourses in consecutive interpretation must also go through the discourse transformation process. So we take discourse transformation as a necessary property in consecutive interpretation. The following discourse is recorded from the consecutive interpreting performed by Zhang Jianmin (a senior interpreter with the Ministry of Foreign Affairs, People's Republic of China) at the press conference hosted by Premier Zhu Rongji for the third session of the Ninth People's Congress (2002). ${ }^{10}$

(1)今年 $(\mathrm{t})$ 国民经济发展的预测的目标定为 $7 \%$ 是经过我们周密考虑的 $(\mathrm{r})$ 。(2)考虑了

(t)各方面的不利因素 $(r)$, (3)包括( $\mathrm{t}$ )世界经济增长速度的减缓等等因素 $(r)$, (4) 来

$(\mathrm{t})$ 考虑制订的 $(r)$ 。(5)我 $(\mathrm{t})$ 想是可以实现的 $(r)$ 。(6)那么具体的措施呢 $(t)$, 我已经在我 的政府工作报告中作了简述 $(r)$ 。(7) 我 $(\mathrm{t})$ 就不再重复了 $(r)$ 。(8)根据今年一季度的执行 情况来看 $(\mathrm{t})$, 比我预想的要好 $(\mathrm{r})$ 。(9)根据国家统计局的预测 $(\mathrm{t})$, 今年第一季度增长 率, GDP的增长率比去年同期增长 $7.5 \%(r)$ 。(10)因此, 我 $(\mathrm{t})$ 对此更有信心 $(\mathrm{r})$ 。(11) 也就 是说完成 $7 \%(\mathrm{t})$ 有信心 $(\mathrm{r})$ 。

Premier Zhu

The theme-rheme organization for this discourse is:

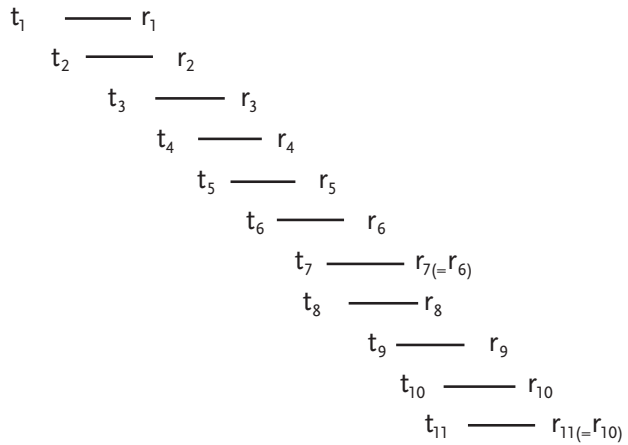

Therefore, the $\mathrm{SM}_{2}$ for this discourse is:

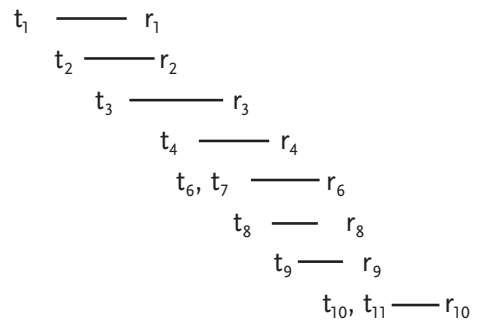


Now, let's come to the interpretation, which corresponds to $\mathrm{SM}_{2}$ :

It is true that we have set our forecast of our economic growth rate at $7 \%$. And this figure is arrived at after we have given careful consideration to all the factors, including the adverse factors such as the slowdown in the world economic growth. So $7 \%$ is within reach. As for the specific measures we are going to adopt to achieve this growth rate, I have already outlined the measures in the report on the working of the government. Judging from our economic performance in the $1^{\text {st }}$ quarter of this year, the result is actually better than I've expected. According to the forecast of the State Statistics Bureau, the GDP of the $1^{\text {st }}$ quarter of this year will grow by $7.5 \%$ over the same period of last year. And this gives me more confidence that we'll be able to achieve the 7\% growth rate.

Sometimes it occurs that the discourse contains little redundant information. The following discourse is recorded from the consecutive interpreting performed by Zhu Tong (a senior interpreter with the Ministry of Foreign Affairs, People's Republic of China) at the press conference hosted by Premier Zhu Rongji for the second session of the Ninth People's Congress, PRC. (1998). ${ }^{11}$ The question is raised by a correspondent with Time magazine. Due to preparations beforehand, the question hardly contains redundant information.

(1)Premier Zhu, you are going to the United States in a few days. (2)But given the bad anti-China mood in Washington, it looks that you are going to walk into another minefield. (3)They accused China there of spying and of stealing sensitive information which you then use to improve the military technology that threatens America's security. (4)How do you react to that, to such accusations? (5)What can you do to improve or to change perception of China in United States? (6)Some politicians in Washington are calling for a reevaluation of the engagement policy with China. (7)Is it still worthwhile for you, for China to be a friend of United States even if they seem don't like you? (8)Thank you.

The thematic progression of this discourse is as follows:

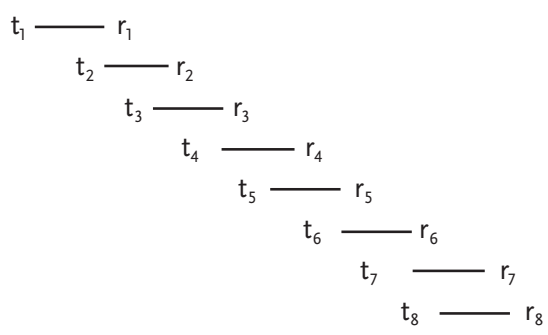

Generally speaking, the source discourse already forms the optimal model and little room exists for macro-rule maneuver; otherwise the quantity of the discourse will be detrimentally reduced. The following is Zhu Tong's interpretation:

朱F基总理, 再过几天您就前往美国进行访问, 并且考虑到在华盛顿出现的这种不好 的反华情绪, 看来您的美国之行就好像踏入另一片雷区。在华盛顿, 人们在指责中国 从事间谍活动, 或者是偷窃一些敏感的高技术的情报用来提高中国自己的军事技术, 这对美国的安全构成了威胁。您对这样的指责是作如何的反应? 另外, 您打算怎么样 做来改变美国人对中国的看法? 在美国华盛顿, 有一些政客他们要求重新来审查一下 对华奉行的接触政策。在看起来好像美国不太喜欢中国的情况下, 您认为您或者是中 国仍然把美国当作您的朋友值不值得? 
In conclusion, we come up with the following discourse transformation model:

FIGURE 1

\section{Discourse transformation model in consecutive interpretation}

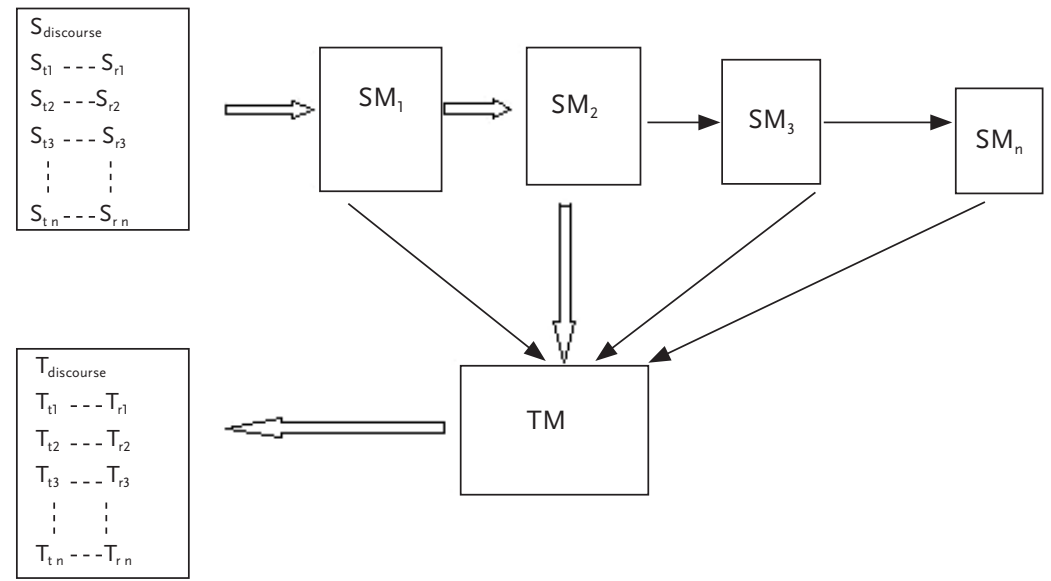

( $\mathrm{S}=$ Source; $\mathrm{T}=$ Target; $\mathrm{t}=$ theme; $\mathrm{r}=$ rheme; $\mathrm{M}=$ Macrostructure; $\mathrm{SM}_{2}$ is the optimal discourse transformation model; SM1 and SM3 are the second best models, the models from $\mathrm{SM}_{3}$ to $\mathrm{SM}_{\mathrm{n}}$ becomes less and less valid; The transformation of $\mathrm{SM}_{1} \rightarrow \mathrm{SM}_{\mathrm{n}}$ is based on Macro Rules One, Two and Three; SM and TM share a common semantic representation; The transformation of $\mathrm{TM} \rightarrow \mathrm{T}_{\text {text }}$ is based on the rules governing the difference between the semantic representation and the surface structure of the target discourse.)

\section{Conclusions}

We are of the opinion that discourse shall be the working unit in consecutive interpreting. To be accurate and timely at once in consecutive interpreting, we cannot but achieve an optimal balance between faithfulness and translational validity. The way out is discourse transformation in line with macro-rules: deletion, construction and generalization. In addition, discourse may be condensed in rounds. The optimal discourse transformation model in consecutive interpreting is $\mathrm{SM}_{2}$, the macrostructure generated from the second round of discourse transformation. It embodies the following features at once:

(1) It is fully capable of imitating the source discourse system rationally, effectively and abstractedly;

(2) It is composed of the least number of essential constituents of the source discourse system possible, thus posing minimal load;

(3) It explicitly demonstrates the organic interrelationships between the constituents;

(4) It stands as close to the standard form as possible.

In addition, as a byproduct, we also tentatively advance a revised version of Gile's Effort Model, which consists of two modules:

Module One:

When TR $\leqq \mathrm{TA}$, Gile's Effort Model is valid in consecutive interpretation;

Module Two:

When TR $>$ TA, Gile's Effort Model is invalid. To compensate, discourse transformation in consecutive interpretation is a must. Macro-rules are implemented in the sequence 
of deletion, construction and generalization, which are recursive. The discourse transformation persists until the TR and TA strike a balance.

Of course, the thinking process is, in fact, not as evident as we have outlined. $\mathrm{SM}_{2}$, the macrostructure derived form the second round of discourse transformation, is merely proposed as a theoretical hypothesis. It might not be $100 \%$ achieved in real-time interpreting settings, but it is our aim. In fact, only well-trained and expert interpreters can generate $\mathrm{SM}_{2}$ by using macro-rule strategies; hence the validity of this model is limited and requires further empirical evidence.

\section{NOTES}

1. L: Listening and Analysis; N: Note-taking; M: Short-term Memory Operations; C: Coordination.

2. Rem: Remembering; Read: Note-reading; P: Production.

3. R: capacity requirements; A: capacity available; TA: total available processing capacity.

4. As Gile (1995: 181) himself stated that notes do not reproduce the speech and they are only written indications to help the interpreter to remember. Seleskovitch (1975: 120, cited from Pöchhacker 2004: 124) also pointed out that interpreters need to divide their attention between the conceptual processing of input and the taking of notes, and that the latter must not detract attention needed for comprehension processes. Therefore, we do not take note-taking into account.

5. One number stands for one clause in the discourse.

6. (1) All operations satisfy the Entailment relation. That is, after the application of any operation the resulting macro-propositions are entailed by the micro-structures. Macro-operations are reducing information by several kinds of Abstraction: irrelevant detail, normal properties or constituents, subset specifications, or necessary properties and constituents are not referred to by the macropropositions. In other words, the operations define what is relatively important in a passage. (2) The first and the second rules are Selective, whereas the third and the fourth rules are Constructive. The selective operations are of the deleting type, whereas the constructive operations are of the substituting type. (3) The macro-rules formulated above are recursive. That is, whenever there is a sequence of propositions satisfying the conditions a new macrostructure at a more general level will be formed. Therefore, a discourse may have levels of macrostructure: M, M2, M3, ---, Mn, where $\mathrm{Mn}$ is the general macrostructure of the discourse as a whole. (4) The operations will apply only if the input is at least two propositions.

7. $\mathrm{t}$ refers to theme, $\mathrm{r}$ refers to rheme, and $\mathrm{T} 1+\mathrm{R} 1$ refers to a clause.

8. The annual People's Congress is the most important political event in China, at which major policies for the coming year are laid down and disclosed. Every year, the affair draws hundreds of journalists at home and abroad. It is generally believed among peers that the interpretation and the interpreters involved at this conference represent the highest level in the field.

9. The recording was made by the author.

10. The recording was made by the author.

11. The recording was made by the author.

\section{REFERENCES}

Baddeley, Alan (1986): Working Memory. Oxford: Oxford University Press.

BAKer, Mona (1992): In Other Words: A Coursebook on Translation. London: Routledge.

BeAugrande, Robert and Dressler, Wolfgang (1981): Introduction to Textlinguistics. London: Longman.

Bierwisch, Manfred (1965): Review of Z. S. Harris: Discourse Analysis Reprints. Linguistics 13(1):61-73.

Casado, Beatriz (1996): Mental Processes Involved in Conference Interpreting: Verbal Fluency. Unpublished M.A. thesis, Université de Genève.

Chincotta, Dino and Underwood, Geoffrey (1998): Simultaneous Interpreters and the Effects of Concurrent Articulation on Immediate Memory: A Bilingual Digit Span Study. Interpreting. 3(1):1-20. 
Dam, Helle (1993): Text Condensing in Consecutive Interpreting. In Gambier,Yves and TomMOLA, Jorma (eds.) Translation and Knowledge: SSOTT IV. Turku: University of Turku, Center for Translation and Interpreting, 77-89.

Gile, Daniel (1995): Basic Concepts and Models for Interpreter and Translator Training. Amsterdam: John Benjamins.

Halliday, M A. K. (1973): Explorations in Functions of Language. London: Edward Arnold.

Halliday, M A. K. (1994): An Introduction to Functional Grammar. London: Edward Arnold.

Hatim, Basil and Mason, Ian (2002): Interpreting: a text linguistic approach. In: PöchHACKer, Franz and Shlesinger, Miriam (eds.) The Interpreting Studies Reader, London: Routledge, 255-265.

Herbert, Jean (1952): The Interpreter's Handbook: How to become a conference interpreter. Geneva: Georg.

Ivanova, Adelina (1999): Discourse Processing during Simultaneous Interpreting: An Expertise Approach. Unpublished Doctoral dissertation, University of Cambridge.

Kintsch, Walter and Van Dijk, Teun A. (1978): Toward a Model of Text Comprehension and Production. Psychological Review. 85(5):363-94.

Köpke, Barbara and Nespoulous, Jean-Luc (2006): Working Memory Performance in Expert and Novice Interpreters. Interpreting. 8(1):1-23.

Li, Rongbao, and Peng, Danling (1999): The Semantic Representation of Bilinguals. Modern Foreign Languages. 3:255-272.

Liu, Minhua, Schallert, Daniel, and Carrol, Patrick (2004): Working Memory and Expertise in Simultaneous Interpreting. Interpreting. 6(1):19-42.

Mackintosh, Jennifer (1985): The Kintsch and Van Dijk Model of Discourse Comprehension and Production Applied to the Interpretation Process. Meta. 30(1):37-43.

Miller, George (1956): The Magical Number Seven, Plus or Minus Two: Some Limits on Our Capacity for Processing Information. Psychological Review. 63(2):81-97.

Moser-Mercer, Barbara (2000): Simultaneous Interpreting: Cognitive Potential and Limitations. Interpreting. 5(2):83-94.

Nordet, Lilan and Voegtlin, Lara (1998): Les Tests d'aptitude pour l'interprétation de Conférence: La Mémoire. Mémoire pour l'obtention du Diplôme de Traducteur, Université de Genève.

Padilla Benítez, Presentación (1995): Procesos de Memoria y Atencion en la Interpretación de Lenguas. Tesis Doctoral, Universidad de Granada.

PöchHACKer, Franz (2004): Introducing Interpreting Studies. London: Routledge.

Renkema, Jan (2004): Introduction to Discourse Studies. Amsterdam: John Benjamins.

Sunnari, Marianna (1995): Processing Strategies in Simultaneous Interpreting: 'Saying it' vs. Synthesis. In: Tommola, Jorma (ed.) Topics in Interpreting Research. Turku: University of Turku, Center for Translation and Interpreting, 109-119.

VAN DijK, Teun A. (1972): Some aspects of text grammars. The Hague: Mouton.

VAN Dijk, Teun A. (1977): Text and Context. London: Longman.

VAN Dijk, Teun A. (1980): Macrostructures. Hillsdale: Lawrence Erlbaum Associates.

VAN DijK, Teun A. and Kintsch, Walter (1983): Strategies of Discourse Comprehension. New York: Academic Press. 